\title{
Third-generation feed stocks for the clean and sustainable biotechnological production of bulk chemicals: synthesis of 2-hydroxyisobutyric acid
}

\author{
Denise Przybylski, Thore Rohwerder, Hauke Harms and Roland H Mueller
}

\begin{abstract}
Background: The synthesis of 2-hydroxyisobutyric acid (2-HIB), a promising building block for, e.g., Plexiglas ${ }^{\circledR}$ production, is described as an example for a clean and sustainable bioproduction.

Methods: A derivative strain of Cupriavidus necator H16, impaired in the poly- $\beta$-hydroxybutyrate synthesis pathway and equipped with xenogenic 2-hydroxyisobutyryl-coenzyme A mutase from Aquincola tertiaricarbonis L108, was applied. Batch cultivation was performed in the presence of vitamin B12 by supplying a gas mixture comprising hydrogen, oxygen, and carbon dioxide.

Results: Exploiting the chemo-litho-autotrophic potential of this so-called knallgas bacterium, 2-HIB was synthesized and excreted into the cultivation broth under aerobic conditions when inorganic nitrogen-limited conditions allowed an overflow metabolism of carbon metabolites. 2-HIB synthesis proceeded at a rate of $8.58 \mathrm{mg} /[(\mathrm{g}$ bacterial dry mass). $\mathrm{h}]$. Approximately $400 \mathrm{mg} / \mathrm{L}$ in total was obtained. The results were subsequently compared to calculated model data to evaluate the efficiency of the conversion of the substrates into the product. To achieve overall yield data regarding the substrate conversion, the model describes an integral process which includes both 2-HIB synthesis and biomass formation.

Conclusions: This study has confirmed the feasibility of the microbial synthesis of the bulk chemical 2-HIB from

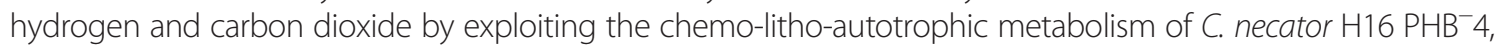
additionally expressing the foreign 2-HIB-coenzyme A mutase. The product synthesis was satisfying as a proof of principle but does not yet approach the maximum value as derived from the model data. Furthermore, the biosynthesis potential of an optimized process is discussed in view of its technical application.
\end{abstract}

Keywords: Bulk chemical synthesis, Renewable carbon sources, Third-generation feed stocks, Hydrogen, Carbon dioxide, 2-hydroxyisobutyric acid, Sustainability

\section{Background}

A growing global population and rising living standards inevitably enforce the conflict between satisfying the people's demands for goods and services, on one hand, and the sustainable development requirements and the considerate treatment of nature and earth's resources, on the other. It is not only that fossil carbon sources will become limited in the future, but there is also a growing pressure to renounce the exploitation of currently treated and prospected sites for environmental reasons.

\footnotetext{
* Correspondence: r.mueller@ufz.de

UFZ - Helmholtz Centre for Environmental Research, Permoserstrasse 15, Leipzig 04318, Germany
}

\section{勿

Accidents, such as the recent oil disaster in the Gulf of Mexico, motivate this tendency even more. To stop the rigorous and reckless exploitation of the earth's resources, alternative resources must be recovered, and clean techniques have to be developed, offered, and applied. The turnaround in thinking and acting has been already evident in recent times, mostly with respect to energy production, for which sustainable resources and clean techniques are increasingly implemented to substitute today's oil and coalbased production [1].

Likewise to the issue of clean energy production, a change is necessary in the societies' approach of how to improve the future production of commodities [2-4]. 
Thereby, industrial (white/green) biotechnology offers an elegant way to provide alternatives [5-7] via the application of microorganisms or components of cells in combination with a broad spectrum of new-generation renewable substrates.

Applying biotechnological processes, the chemical industry has for ages produced, for instance, alcohols and organic acids mainly to be employed as chemicals, but above all as energy carriers in bulk quantities. Of those, bioethanol [8-11] is a recent example of modern fuels for motor vehicles [12], while biobutanol is expected to be another one $[13,14]$. Based on this knowledge of how to produce bulk-scale energy carriers, recent intentions envisage the extension of platform chemicals for wider applications [13,15-18]. Special attempts are directed towards the synthesis of chemicals, such as 1,3-propanediol [19], succinate [20], gluconic acid [21-23], or citric acid [24]. Likewise, 2-hydroxyisobutyric acid (2-HIB) fits well into this scheme as it is gaining importance as a platform chemical. In particular, it can be used as a precursor for methacrylic acid [15,25], a monomeric compound required for the synthesis of such prominent products like Plexiglas ${ }^{\circledR}$ (Evonik Röhm GmbH, Essen, Germany) and as an important ingredient for coating materials, paint, and glues.

In general, traditional biotechnological processes, such as those for bioethanol production, are based on carbon sources of the so-called first generation, i.e., carbohydrates such as sugars or starches directly derived from plants [26]. Nowadays, the focus has shifted to secondgeneration feed stocks $[11,27]$, which rely on complex plant materials, such as cellulose, hemicellulose, and lignin; the monomers of which are, however, more difficult to access [28], especially in terms of biosynthesis. Additionally, the concept of using arable land to grow plants solely as substrate resources for biotechnological processes is a matter of controversial debate, not only in view of substituting natural biotopes (e.g., rain forests) by monocultures [29], but also in view of reasonable conflicts with nutritional issues and the food production industry [30,31].

One solution and actual expectation in terms of a future sustainable bulk chemical production is the utilization of substrates of the third generation, i.e., diverse gas mixtures which deliver carbon as well as reducing power from different sources $[4,32,33]$. This implies the utilization of $\mathrm{CO}_{2}$ as a carbon source since $\mathrm{CO}_{2}$ accumulates as a waste product of energy production from fossil resources. At the same time, the resulting consumption of $\mathrm{CO}_{2}$ within such a new production scheme also provides a fundamental argument to support processes that counteract climate change [13,34]. The required reducing power might be delivered by hydrogen generated, e.g., by solar energy [35] or wind power [36]. Some perspectives of how to use $\mathrm{CO}_{2}$, not only as a substrate for diverse syntheses, but also for various biosyntheses, have recently been presented at the Dechema colloquium [37,38]. Among others, the processes developed by Coskata Inc., Illinois, USA, employing a variety of materials which can be converted into renewable fuels and chemicals by biofermentation of synthesis gas, have been demonstrated. Also, the development of special designer bugs, being capable of using flue gas as a substrate, has been introduced at the colloquium Sustainable Bioeconomy [39]. However, the biggest challenge of those miscellaneous approaches is and will be the competition with the established processes and the implemented production schemes of the chemical industry $[3,31,40]$, where the biobased synthesis is often still defeated. Nevertheless, in this investigation, another perspective of how to use $\mathrm{CO}_{2}$ to sustainably produce 2-HIB as a building block is presented.

We recently discovered a novel enzyme, the 2-HIBcoenzyme A mutase, which proves to be an ideal catalyst for the production of 2-HIB, especially, given that 2-HIB synthesis with this enzyme only requires a one-step isomerization of metabolites that are essential for the metabolism of a wide range of bacteria, i.e., 3-hydroxybutyryl-coenzyme A (3-HB-CoA) [25,41-44]. The synthesis of 2-HIB and its excretion into the cultivation broth can be realized by employing strains that express this heterologous enzyme in combination with an existing overflow carbon metabolism. The selection of suitable strains thus allows different substrates for the production of 2-HIB to be utilized, as has been demonstrated by using fructose [45, D Przybylski, unpublished work]. However, in seeking sustainability, the application of fructose, a substrate of the first generation, will not meet the requirements to qualify carbohydrates as future substrates.

Therefore, we have applied the 2-HIB-coenzyme A mutase to demonstrate the sustainable and clean production of 2-HIB from carbon dioxide and hydrogen by exploiting the chemo-litho-autotrophic metabolism of the knallgas bacterium Cupriavidus necator (Alcaligenes eutrophus) $\mathrm{H} 16 \mathrm{PHB}^{-} 4$ [46,47]. The synthesis of 2-HIB was successful at the experimental proof of principle stage. Model data were added to confirm the metabolic potential of such a process.

\section{Methods}

\section{Bacterial strains and plasmids}

C. necator, strain $\mathrm{H} 16 \mathrm{PHB}^{-} 4$ DSM 541 [47], was obtained from the DSMZ (Leibniz-Institut DSMZ - Deutsche Sammlung von Mikroorganismen und Zellkulturen $\mathrm{GmbH}$, Braunschweig, Germany) and modified by introducing the plasmid pBBR1MCS-2::HCM [48], which originates from the broad-host-range cloning vector pBBR1MCS [49]. The plasmid contains the genes $h c m A$ and $h c m B$ coding for the 
two subunits of the 2-hydroxy-isobutyryl-coenzyme A mutase from Aquincola tertiaricarbonis L108 [41,44]. The plasmid was kindly provided by Evonik Industries AG (Marl, Germany).

\section{Cultivation conditions}

The general cultivation was performed in Luria Bertani broth (Miller) at $30^{\circ} \mathrm{C}$, and the strain was stored on LBagar plates at $4^{\circ} \mathrm{C}$. For batch cultivations, a mineral salt medium was used, as described by Schlegel and coauthors [50] supplied with $0.3 \mathrm{mg} / \mathrm{L}$ kanamycin and 50 $\mathrm{mg} / \mathrm{L}$ vitamin B12.

The pre-cultures were prepared from single colonies at $30^{\circ} \mathrm{C}$ and 150 rounds per minute (rpm) in $200 \mathrm{~mL}$ of the same medium with fructose as the sole carbon source under aerobic conditions. After fructose exhaustion, the pre-culture was used to inoculate a fresh culture which was immediately shifted to hydrogen and carbon dioxide. The cultivation continued in a batchwise manner under laboratory conditions at $22^{\circ} \mathrm{C}$, using a shake flask equipped with a stirrer and containing a working volume of $0.6 \mathrm{~L}$, gassed with a sterile mixture of $\mathrm{H}_{2}: \mathrm{O}_{2}: \mathrm{CO}_{2}$ in variable ratios. Agitation was set to $200 \mathrm{rpm}$. The two gases apart from oxygen were supplied from a storage tank with a volume of $18 \mathrm{~L}$ treated according to the gasometer principle. The initial gas concentrations were about $25 \%$ to $50 \% \mathrm{H}_{2}, 15 \%$ to $30 \% \mathrm{CO}_{2}$, and $10 \%$ to $20 \%$ $\mathrm{O}_{2}$. The gases were supplied to the culture by a hollow fiber module (Fresenius, St. Wendel, Germany), using a membrane pump at a feeding rate of 750 $\mathrm{mL} / \mathrm{min}$ moving a gas circuit. Hollow fibers had a pore width of $0.2 \mu \mathrm{m}$ and a specific exchange area of $0.7 \mathrm{~m}^{2}$. The external volume of the hollow fiber module was flushed with the bacterial suspension at a rate of $42.6 \mathrm{~L} / \mathrm{h}$, fed with a gear pump out of the shake flask. After passage through the module, the gases and the suspension were collected in the flask and separated from each other. The gases were recirculated to the gas tank and mixed with the residing gases by a propeller by means of a magnet-coupled motor installed outside of the tank, whereas the suspension was re-fed to the module. The consumption of gases was monitored both in terms of the change of the total volume, which was registered by the horizontal movement of the gas tank, and in terms of the concentration measured by three specific sensors. If required, specific gases were refilled into the gas tank. As there was no automated $\mathrm{pH}$ control in this simplified cultivation system, the $\mathrm{pH}$ was monitored off-line and adjusted to $\mathrm{pH} 7.0$ by adding the required volumes of $10 \% \mathrm{NaOH}$ according to a titration curve based on the growth medium.

\section{On-line analysis}

The gas concentrations were measured by specific sensors for hydrogen ( $0 \%$ to $100 \%)$, oxygen ( $0 \%$ to $100 \%)$, and carbon dioxide ( $0 \%$ to $50 \%$ ) (BlueSens, Herten, Germany) and were continuously monitored.

\section{Off-line analysis}

The biomass concentration was monitored by the optical density at $700 \mathrm{~nm}$ (U-2000 Spectrophotometer, Hitachi High-Technologies Corporation, Tokyo, Japan) and converted into bacterial dry mass according to a calibration curve prepared earlier. The substrate consumption and 2HIB synthesis were analyzed by isocratic HPLC (Shimadzu Corporation, Kyoto, Japan) using a Nucleogel Ion 300 OA column $(300 \times 7.8 \mathrm{~mm}$, Macherey-Nagel GmbH \& Co. KG, Düren, Germany) at $70^{\circ} \mathrm{C}$ with $0.6 \mathrm{~mL} / \mathrm{min} 0.01 \mathrm{~N} \mathrm{H}_{2} \mathrm{SO}_{4}$ as the eluant.

\section{Evaluation methods}

The gas consumption was calculated from the differential changes of the total and individual gas concentrations by means of simple linear regression for the different phases of the fermentation.

\section{Calculations}

3-Phosphoglycerate (PGA) was defined as the central carbon precursor $[51,52]$ from which the complete biomass synthesis was derived. The molar composition of the biomass in the model was taken as $\mathrm{C}_{4} \mathrm{H}_{8} \mathrm{O}_{2} \mathrm{~N}$. It is synthesized from adenosine triphosphate (ATP) as the general energy carrier and proceeds with an efficiency of $10.5 \mathrm{~g}$ bacterial dry mass pro mol ATP [53]. The overall balance equation for the biomass synthesis from PGA is as follows:

$$
\begin{aligned}
4 \mathrm{PGA} & +29.1 \mathrm{ATP}+3 \mathrm{NH}_{3} \\
& +5.5[2 \mathrm{H}] \rightarrow 3 \mathrm{C}_{4} \mathrm{H}_{8} \mathrm{O}_{2} \mathrm{~N}+10 \mathrm{H}_{2} \mathrm{O} .
\end{aligned}
$$

$[2 \mathrm{H}]$ denotes the reduction equivalents, which in general correspond to reduced nicotinamide adenine dinucleotide (phosphate) $\left\{\mathrm{NAD}(\mathrm{P}) \mathrm{H}+\mathrm{H}^{+}\right\}$.

\section{Results and discussion \\ Theoretical product yields}

To define the possible product yields in a growthassociated process, we applied a stoichiometric model. Knallgas bacteria such as $C$. necator use the Calvin cycle to assimilate carbon and the enzyme hydrogenase to gain $\mathrm{NAD}(\mathrm{P}) \mathrm{H}+\mathrm{H}^{+}$from hydrogen as a substrate for the oxidative phosphorylation via the respiratory chain as well as a source for carbon dioxide reduction. Therefore, the overall balance equation for biomass synthesis via PGA including the energy generation from $\mathrm{H}_{2}$ oxidation at a degree of coupling in the oxidative 
phosphorylation by the respiratory chain of $\mathrm{P} / \mathrm{O}=2$ results in

$$
\begin{aligned}
12 \mathrm{CO}_{2} & +3 \mathrm{NH}_{3}+56.05\left[\mathrm{H}_{2}\right] \\
& +15.28 \mathrm{O}_{2} \rightarrow 3 \mathrm{C}_{4} \mathrm{H}_{8} \mathrm{O}_{2} \mathrm{~N}+48.55 \mathrm{H}_{2} \mathrm{O} .
\end{aligned}
$$

With respect to growth, this corresponds to a carbon conversion efficiency (CCE) of one molecule of carbon (Cmol) incorporated per $\mathrm{Cmol}$ supplied and a hydrogen conversion efficiency (HCE) of 0.214 molecules of hydrogen $(\mathrm{Hmol})$ assimilated per $\mathrm{Hmol}$ consumed. The synthesis of 2- $\mathrm{HIB}\left(\mathrm{C}_{4} \mathrm{H}_{8} \mathrm{O}_{3}\right)$ as the desired product via the Calvin cycle with PGA and pyruvate as intermediates results in acetyl-CoA (AcCoA) according to

$$
4 \mathrm{CO}_{2}+8\left[\mathrm{H}_{2}\right]+14 \mathrm{ATP} \rightarrow 2 \mathrm{AcCoA}+4 \mathrm{H}_{2} \mathrm{O} .
$$

The ATP required for $\mathrm{CO}_{2}$ fixation is obtained from hydrogen oxidation via the respiratory chain; accordingly, Equation 3a is extended to

$$
4 \mathrm{CO}_{2}+16\left[\mathrm{H}_{2}\right]+3.5 \mathrm{O}_{2} \rightarrow 2-\mathrm{HIB}+12 \mathrm{H}_{2} \mathrm{O} \text {. }
$$

The CCE is again $1 \mathrm{Cmol} / \mathrm{Cmol}$, whereas the theoretical $\mathrm{HCE}$ is $0.25 \mathrm{Hmol} / \mathrm{Hmol}$ (Equation 3b). Combining biomass synthesis and product formation to an integral process, the interdependency between both processes defining the final HCE with respect to the product is shown in Figure 1. We took into account two ranges of biomass concentrations (from 0 to $10 \mathrm{~g} / \mathrm{L}$ and from 10 to $60 \mathrm{~g} / \mathrm{L}$ ) to consider a wide spectrum of variables. Obviously, biomass synthesis is very costly (Equation 2). It is apparent that the overall process approaches a value of 0.2 to $0.25 \mathrm{Hmol} / \mathrm{Hmol}$, when the biomass concentration is below $10 \mathrm{~g} / \mathrm{L}$, and the product concentration moves towards $100 \mathrm{~g} / \mathrm{L}$ (Figure 1). Both the increase in biomass and the reduction of product concentration drastically decrease the HCE.

\section{Experimental data: growth}

The growth characteristics under chemo-litho-autotrophic conditions were examined, thereby displaying a rate of about $0.066 / \mathrm{h}$, which is lower by a factor of about $4 \mathrm{com}$ pared to an optimized cultivation regime for the cultivation of C. necator H16 [47,54-56]. Rates reduced by a factor of about 2 are expected, when applying lower temperatures, $22^{\circ} \mathrm{C}$ in our case compared to $31^{\circ} \mathrm{C}$ used by former authors. Moreover, the polyhydroxyalkanoate (PHA) synthesisdeficient mutant strain was shown to have a reduced hydrogen oxidation rate compared to the wild type [57]. We used a closed circuit system to recycle the gases in combination with a hollow fiber module as an interface between the gases and the liquid phase for safety reasons due to the explosive character of the gas mixture and due to the necessity of enabling elevated gas transfer conditions under those simplified cultivation conditions. This system has not been further optimized with respect to the transfer rates of the various substrates. Nevertheless, the exponential growth pattern indicates that the substrate supply was not limiting for the biomass concentration applied (Figure 2). Moreover, the results suggest that the cultivation system chosen is in fact adequately efficient in delivering the gaseous substrates for the product synthesis.

\section{Experimental data: product formation}

We used the strain $C$. necator $\mathrm{H}_{16} \mathrm{PHB}^{-} 4$ [47], a PHAnegative mutant, in which the poly- $\beta$-hydroxybutyric acid

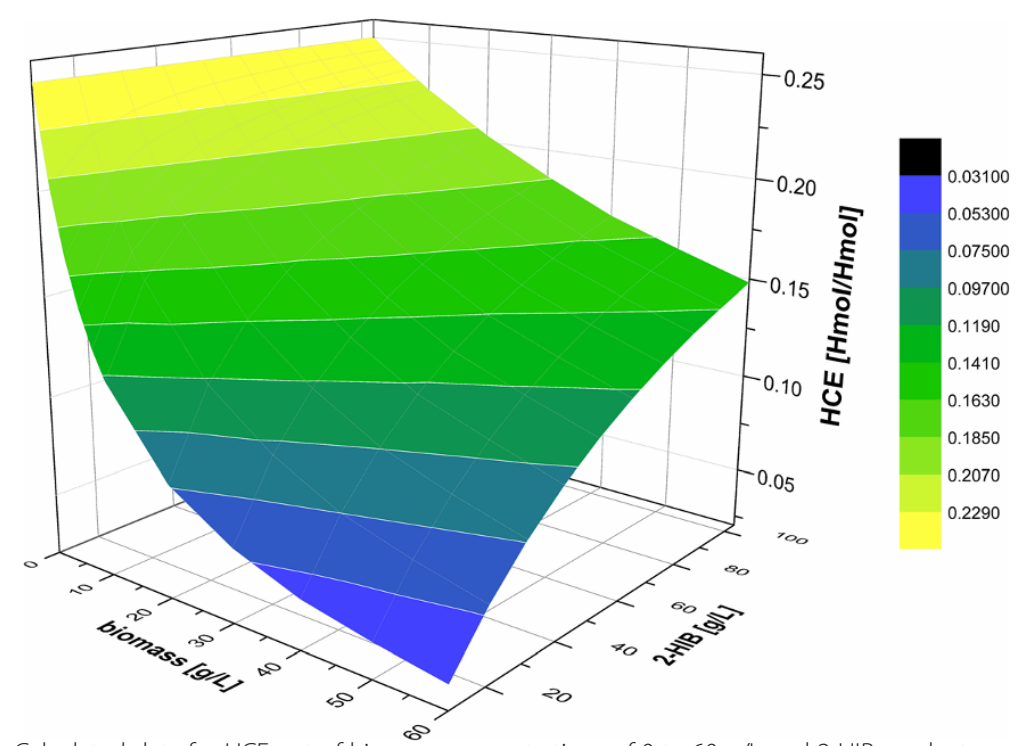

Figure 1 HCE model data. Calculated data for HCE out of biomass concentrations of 0 to $60 \mathrm{~g} / \mathrm{L}$ and 2-HIB product concentrations of 0 to $100 \mathrm{~g} / \mathrm{L}$. 


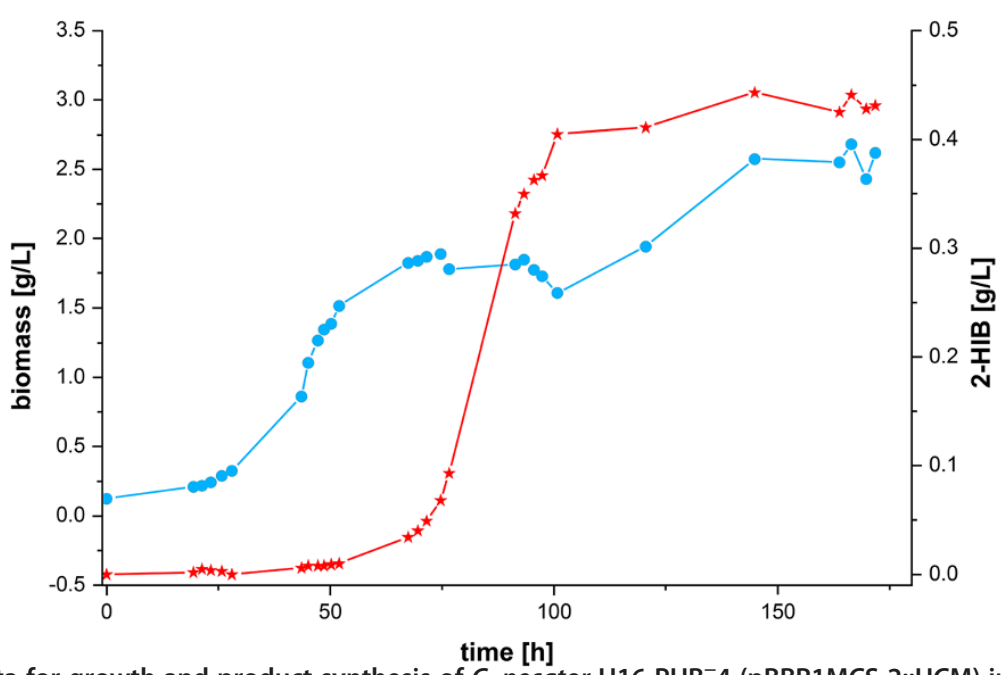

Figure 2 Experimental data for growth and product synthesis of $\mathrm{C}$. necator $\mathrm{H}_{16} \mathrm{PHB}^{-} 4$ (pBBR1MCS-2::HCM) in chemo-litho-autotrophic fermentation. Growth phase (0 to $60 \mathrm{~h}$ ) and product synthesis phase (60 to $160 \mathrm{~h}$ ) with biomass (blue circle) and 2-HIB (red star) in g/L.

(PHB) synthesis is blocked subsequent to the synthesis of 3-HB-CoA. Introduction of the 2-HIB-CoA mutase from A. tertiaricarbonis allowed this strain to synthesize metabolites up to 3 -HB-CoA under conditions of overflow metabolism favoring 2-HIB synthesis through the simultaneous expression of the 2-HIB-CoA mutase. Thereby, an alternative route ensuing $3-\mathrm{HB}-\mathrm{CoA}$ is established to finally yield the desired dead-end product, 2-HIB. To confirm the capacity of the chosen system for 2-HIB synthesis, a fructose pre-grown culture was used to inoculate the cultivation apparatus. A gas stream containing $25 \%$ to $50 \% \mathrm{H}_{2}, 15 \%$ to $30 \% \mathrm{CO}_{2}$, and $10 \%$ to $20 \% \mathrm{O}_{2}$ was supplied as a growth substrate, resulting in the induction of the enzymes required for chemo-litho-autotrophic growth, especially hydrogenases $[58,59]$, and for carbon dioxide fixation [60]. Under these conditions, growth proceeded at a rate of about $0.066 / \mathrm{h}$ until the nitrogen source was exhausted, attaining a final biomass concentration of approximately $2.0 \mathrm{~g} / \mathrm{L}$ (Figure 2). During exponential growth, carbon dioxide was incorporated into the biomass with a CCE of $0.58 \mathrm{Cmol} / \mathrm{Cmol}$. The hydrogen conversion yielded a HCE of $0.0715 \mathrm{Hmol} / \mathrm{Hmol}$. It should be noted that it is not possible to achieve the theoretically maximum value of the $\mathrm{HCE}$ of $0.214 \mathrm{Hmol} / \mathrm{Hmol}$ due to the required energy $\left(\mathrm{H}_{2}\right)$ necessary for maintenance purposes. Larger deviations from the theoretical values might be caused by the synthesis of side products other than biomass, such as pyruvate [57,61], 3-hydroxybutyric acid, acetone, or 2-oxoglutarate $[62,63]$ depending on the culture conditions applied. More detailed analyses, however, were not undertaken at this stage of the investigation.

During growth, 2-HIB was found, but only at low concentrations. After exhaustion of the nitrogen source, however, there was a steep increase in the external 2HIB concentration (Figure 2). The synthesis rate

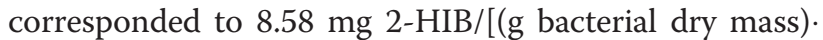
$\mathrm{h}$. This rate was stable up to a total concentration of approximately $410 \mathrm{mg} / \mathrm{L}$. Subsequently, the product synthesis rate suddenly ceased, which was also observed in repeated experiments. The abrupt shift pointed to a distinct limitation or disturbance, which was not evident in the experimental setup. This would require a further optimization.

As described above, the amount of gases consumed per increment of 2-HIB was used to calculate the yield coefficients. The data were corrected for the unspecific loss of gases determined by running experiments in the absence of biomass. The remaining substrate was incorporated into 2-HIB with a CCE of $0.178 \mathrm{Cmol} / \mathrm{Cmol}$. Hydrogen as a second substrate was converted into this product with a $\mathrm{HCE}$ of $0.032 \mathrm{Hmol} / \mathrm{Hmol}$. Noticeably, this is far from the above stated limit values.

The present rates of 2-HIB synthesis with the mutant strain $\mathrm{H}_{16} \mathrm{PBH}^{-} 4$ (pBBR1MCS-2::HCM) were somewhat lower than those found for the formation of PHB with the wild type strain of $C$. necator H16 under chemo-lithoautotrophic conditions yielding up to $12.8 \mathrm{mg} /[$ (g bacterial dry mass).h] $[64,65]$. It is known, however, that the lack of the PHB polymerase (PhaC) activity in this mutant strain is associated with distinctly lower activities of $\beta$-ketothiolase (PhaA) and acetoacetyl-CoA reductase (PhaB) [66].

\section{Deficits in product synthesis}

The deficit in the gain of 2-HIB can likely be explained in part by the putative synthesis of products other than 2-HIB $[57,61,63]$. Taking into account the reduction of $\mathrm{CO}_{2}$ by hydrogen to yield the first intermediate of carbon fixation in the Calvin cycle, glyceraldehyde-3-phosphate (GAP, $\mathrm{C}_{3} \mathrm{H}_{6} \mathrm{O}_{3}$, phosphate-free sum formula), the $\mathrm{CO}_{2}$ available due to the present consumption characteristic will allow 
for the synthesis of $0.57 \mathrm{mmol} \mathrm{GAP} / \mathrm{h}$ in the linear phase of 2-HIB formation. This in turn requires $5.16 \mathrm{mmol} \mathrm{H}_{2} / \mathrm{h}$ based on

$$
\begin{aligned}
& 3 \mathrm{CO}_{2}+9\left[\mathrm{H}_{2}\right]+1.5 \mathrm{O}_{2} \\
& \rightarrow \operatorname{GAP}\left(\mathrm{C}_{3} \mathrm{H}_{6} \mathrm{O}_{3}\right)+6 \mathrm{H}_{2} \mathrm{O} .
\end{aligned}
$$

Due to the hydrogen balance, $5.71 \mathrm{mmol} \mathrm{H}_{2}$ remain available after 2-HIB synthesis which could satisfy the putative product synthesis. Hence, some hydrogen remains additionally available for maintenance purposes which are inevitably necessary in living cells. Taking into account the specific maintenance coefficient determined formerly for Ralstonia eutropha (C. necator) JMP 134 on fructose of $m_{\mathrm{s}}=0.09 \mathrm{mmol} /[(\mathrm{g}$ bacterial dry mass $) \cdot \mathrm{h}]$ [67] and converting this substrate-based coefficient into an energy (ATP)based value $(\mathrm{P} / \mathrm{O}=2)$ which would be equivalent to $m_{\mathrm{e}}=2.34 \mathrm{mmol}$ ATP $/[(\mathrm{g}$ bacterial dry mass $) \cdot \mathrm{h}]$, the hydrogen remaining after the synthesis of 2-HIB and other putative reduced products would be sufficient to generate $2.8 \mathrm{mmol} \mathrm{ATP} /[(\mathrm{g}$ bacterial dry mass $) \cdot \mathrm{h}]$. This is in pretty coincidence with former results regarding this species [67].

\section{Conclusions}

The present results can be regarded as a proof of principle demonstrating the feasibility of 2-HIB synthesis under chemo-litho-autotrophic conditions. Since the yield is still far from technological dimensions, the optimization of this process is necessary to improve its stability with the aim to increase the productivity. This would require a prolonged product synthesis, higher rates, and, in particular, better yields.

Under laboratory and chemo-litho-autotrophic conditions, a 2-HIB synthesis rate of $8.58 \mathrm{mg} /[$ (g bacterial dry mass).h] was achieved, yielding a final concentration of about $0.4 \mathrm{~g} / \mathrm{L}$. The efficiency of this production scheme on the basis of sustainable substrates becomes even more obvious when being compared to the derived rates of 2-HIB formation obtained with the same transgenic strain expressing the 2-HIB mutase and being cultivated under aerobic conditions in a controlled fermenter on fructose as the sole substrate. In the latter case, rates of around 5.8 to $7.2 \mathrm{mg} 2-\mathrm{HIB} /[(\mathrm{g}$ bacterial dry mass).h] were obtained [45, D Przybylski, unpublished work].

The HCE during product synthesis yielded $0.03 \mathrm{Hmol} /$ $\mathrm{Hmol}$, which is distinctly lower than the theoretical value $(0.25 \mathrm{Hmol} / \mathrm{Hmol}) . \mathrm{CO}_{2}$ was incorporated into 2-HIB with an efficiency of $0.18 \mathrm{Cmol} / \mathrm{Cmol}$. The discrepancies are not evident at present but are likely to be explained by additional products formed apart from 2-HIB. This follows from the fact that the available amounts of $\mathrm{CO}_{2}$ and $\mathrm{H}_{2}$, remaining after 2-HIB synthesis, are sufficient to generate reduced primary products (GAP) in the Calvin cycle in an almost stoichiometric manner (cf. Equation 4).

With respect to the overall yield of the 2-HIB synthesis determined in the present investigation, we extracted a substrate conversion efficiency with a total of $0.103 \mathrm{Cmol} /$ $\mathrm{Cmol}$ by taking into account biomass synthesis. This resembles about $63 \%$ of the theoretically possible value $(0.164 \mathrm{Cmol} / \mathrm{Cmol})$ at the respective biomass $(2 \mathrm{~g} / \mathrm{L})$ and product concentration $(0.4 \mathrm{~g} / \mathrm{L})$ according to the treatment of the data as shown in Figure 1. With regard to HCE, the experimental integral value amounted to $0.002 \mathrm{Hmol} /$ Hmol, which is only about $5.5 \%$ of the theoretical value with $0.036 \mathrm{Hmol} / \mathrm{Hmol}$. The absolute output of substrate is far too low. This is essentially caused by the low gain of the desired product and an improper ratio between biomass and product concentration.

A question remaining to be solved is the prolonged synthesis of 2-HIB since the present experiment showed a more or less abrupt halt of product synthesis. The reasons for that have to be thoroughly examined in order to be possibly eliminated in future experiments.

The present investigation was performed under laboratory conditions in a $0.6-\mathrm{L}$ dimension and at a low biomass concentration of around $2 \mathrm{~g} / \mathrm{L}$. Upscaling will illustrate the potential of such a biobased process. Based on the specific rate of $8.58 \mathrm{mg} 2-\mathrm{HIB} /[$ (g bacterial dry mass).h] found in the present investigation, a process extrapolated to the cubic meter dimension would therefore result in the synthesis of approximately $200 \mathrm{~g} 2$ - $\mathrm{HIB}$ $/\left(\mathrm{m}^{3} \mathrm{~d}\right)$ by applying $1 \mathrm{~kg}$ of biomass. Using $10 \mathrm{~kg}$ of biomass and a $10-\mathrm{m}^{3}$ scale, the output will be $20 \mathrm{~kg} /$ day, which corresponds to a production on a semi-technical scale. In general, the chemical industry operates reactors with a size of $1,000 \mathrm{~m}^{3}$ and larger. Due to the obvious reasons, more and more processes will and already do involve gases and thus require experience in handling explosive mixtures. They will not likely involve a membrane technology, as has been used here for safety reasons. Consequently, amounts of tons per day are imaginable without relying on unrealistic assumptions. Higher biomass concentrations will have an even higher impact on the productivity of such a process. In this case, the efficiency of the conversion of the substrates to the final product has to be considered (see Figure 1). An increase in biomass concentration will consequently result in a diminished efficiency of the product synthesis. An optimization at this stage will include considerations about rate versus yield, subsequently leading to decisions based on economic figures.

Another important factor not to be neglected in this context is the usability/durability of the catalyst biomass. The present case assumes a discontinuous production regime since organic acids, as the envisaged product $2-\mathrm{HIB}$, are in general toxic to microorganisms at higher concentrations 
[68-72], e.g., acetic acid being inhibitive above concentrations of $6 \mathrm{~g} / \mathrm{L}$ [73], which is well below the desired product concentration range. However, no thorough investigations with respect to matters of 2-HIB product inhibition have been undertaken at this stage of investigation. But as acid toxicity will have an impact and therefore has to be considered, continuous extraction offers the possibility to reduce the current acid concentration in the production broth with the effect of maintaining the activity of the cells and thus extending the production time. Moreover, a continuous process with intermittent periods of growth to regenerate the catalyst biomass should be considered. Such measures and their effects, however, require detailed investigations which are outside the scope of the present investigation.

The yearly production of Plexiglas ${ }^{\circledR}$ amounts to 3 million tons and is based exclusively on fossil carbon sources. However, it is not imaginable that a process as described here will substitute the established processes in the near future, but the actual constellations contribute to a turnaround in the favor of alternative processes relying on gases. Production and storage of hydrogen on the basis of electricity generated by solar techniques and wind energy is state of the art and will increase in its dimension [35,36,74]. Carbon dioxide, on the other hand, is an unavoidable result of energy production from fossil carbon sources. As the actual discussions address the question of how to get rid of this climate change driver, the removal of this compound from exhaust gases in energy plants and its deposition are currently argued for, and legislation will find ways to implement such solutions. Above all, those factors emphasize even more the necessity of a turn in thinking regarding the handling of our resources while supporting new ideas and developments to move in the direction suggested in this investigation. Moreover, gases derived from biomass, i.e., synthesis gas comprised of hydrogen and carbon monoxide as a result of pyrolysis $[4,75,76]$, are yet another source for product syntheses as the one described here. Adequate pathways are found in diverse microorganisms, such as in anaerobic clostridia. Forthcoming models following the idea of sustainable product synthesis could be directed towards methane as a potential substrate [4] as well, which may be derived from biogas plants or received as a conversion product out of synthesis gas and methanol as its oxidized derivative. The basic metabolic potentials to convert those substrates are available in the respective microorganisms. The decision regarding the kind of substrate to be used for an envisaged product synthesis depends on technological and physiological properties. The final decision then depends on the degree of the required refinement of the educts, which in turn is a question of the effectiveness of substrate conversion and the price of the final product [67].

\section{Abbreviations}

2-HIB: 2-hydroxyisobutyric acid; 2-HIB-CoA: 2-hydroxyisobutyryl-coenzyme A 3-HB-CoA: 3-hydroxybutyryl-coenzyme A; AcCoA: acetyl coenzyme A;
ATP: adenosine triphosphate; CCE: carbon conversion efficiency; Cmol: content of carbon in a molecule; GAP: glyceraldehyde-3-phosphate; HCE: hydrogen conversion efficiency; Hmol: content of hydrogen in a molecule; $\mathrm{NAD}(\mathrm{P}) \mathrm{H}+\mathrm{H}^{+}$: reduced nicotinamide adenine dinucleotide (phosphate); PGA: 3-phosphoglycerate; PHA: polyhydroxyalkanoate; PhaA: $\beta$-ketothiolase; PhaB: acetoacetyl-CoA reductase; PhaC: PHB polymerase; PHB: poly- 3 -hydroxybutyrate; P/O: degree of coupling of phosphate fixation into an energy-rich bond (ATP) during the flow of two electrons via the respiratory chain to reduce oxygen to water; rpm: rounds per minute.

\section{Competing interests}

The authors declare that they have no competing interests.

\section{Acknowledgments}

This investigation was financed by the Fachagentur Nachwachsende Rohstoffe e.V. (FNR)/Bundesministerium für Ernährung, Landwirtschaft und Verbraucherschutz (BMELV), grant FKZ 22027805. The authors are furthermore grateful to the Evonik Industries $\mathrm{GmbH}$ for the support. Additionally, the work of DP was carried out under the mentoring of the HIGRADE Graduate School.

\section{Authors' contributions}

DP conceived the study, participated in its design, and drafted the manuscript. TR and HH participated in the concept and drafted the manuscript. RHM participated in the experimental design, contributed to the model, and drafted the manuscript. All authors have read and approved the final manuscript.

\section{Authors' information}

$\mathrm{HH}$ is the head of the Department of Environmental Microbiology of the UFZ - Helmholtz Centre for Environmental Research and a professor of Microbiology at the University of Leipzig. He is engaged in investigations examining the functioning of microbial communities for driving natural biogeochemical cycles in pollutant degradation as well as in the sustainable management of landscapes and the exploitation of the genetic resources of natural biotopes for research and biotechnology.

RHM is the leader of the group Bacterial Physiology of the Department of Environmental Microbiology of the UFZ - Helmholtz Centre for

Environmental Research. He is involved in fundamental and applied studies on microbial substrate conversion targeting on the degradation of xenobiotics and the synthesis of products.

TR is a senior scientist in the Department of Environmental Microbiology of the UFZ - Helmholtz Centre for Environmental Research and is involved in microbial, enzymatic, and biotechnological investigations directed towards pollutant degradation and product synthesis.

$\mathrm{DP}$ is a doctoral student. She is dealing with biotechnological issues on the application and optimization of properties of the conversion of microbial substrates into distinct products by applying enzymatic, physiological, fermentative, and thermodynamic techniques.

\section{Dedication}

This publication is dedicated to Prof. Wolfgang Babel on the occasion of his 75th birthday.

Received: 20 June 2012 Accepted: 16 July 2012

Published: 16 July 2012

\section{References}

1. Zinoviev S, Mueller-Langer F, Das P, Bertero N, Fornasiero P, Kaltschmitt M, Centi G, Miertus S (2010) Next-generation biofuels: survey of emerging technologies and sustainability issues. Chem Sus Chem 3(10):1106-1133.

2. Willke T, Vorlop KD (2004) Industrial bioconversion of renewable resources as an alternative to conventional chemistry. Appl Microbiol Biotechnol 66(2):131-142.

3. Nordhoff S, Hocker H, Gebhardt H (2007) Renewable resources in the chemical industry - breaking away from oil? Biotechnol J 2(12):1505-1513.

4. Muffler K, Ulber R (2008) Use of renewable raw materials in the chemical industry - beyond sugar and starch. Chem Eng Technol 31(5):638-646.

5. Hatti-Kaul R, Tornvall U, Gustafsson L, Borjesson P (2007) Industrial biotechnology for the production of bio-based chemicals - a cradle-to-grave perspective. Trends Biotechnol 25(3):119-124. 
6. Roes AL, Patel MK (2007) Life cycle risks for human health: a comparison of petroleum versus bio-based production of five bulk organic chemicals. Risk Anal 27(5):1311-1321.

7. Dornburg V, Hermann BG, Patel MK (2008) Scenario projections for future market potentials of biobased bulk chemicals. Environ Sci Techno 42(7):2261-2267.

8. Hahn-Haegerdal B, Galbe M, Gorwa-Grauslund MF, Lidén G, Zacchi G (2006) Bio-ethanol - the fuel of tomorrow from the residues of today. Trends Biotechnol 24(12):549-556.

9. Otero JM, Panagiotou G, Olsson L (2007) Fueling industrial biotechnology growth with bioethanol. Adv Biochem Eng Biotechnol 108:1-40.

10. Mussatto SI, Dragone G, Guimaraes PM, Silva JP, Carneiro LM, Roberto IC, Vicente A, Domingues L, Teixeira JA (2010) Technological trends, global market, and challenges of bio-ethanol production. Biotechnol Adv 28(6):817-830.

11. Singh A, Pant D, Korres NE, Nizami AS, Prasad S, Murphy JD (2010) Key issues in life cycle assessment of ethanol production from lignocellulosic biomass: challenges and perspectives. Bioresource Technol 101(13):5003-5012.

12. Kohse-Hoinghaus K, Osswald P, Cool TA, Kasper T, Hansen N, Qi F, Westbrook CK, Westmoreland PR (2010) Biofuel combustion chemistry: from ethanol to biodiesel. Angew Chem Int Ed Engl 49(21):3572-3597.

13. Dürre $P$ (2008) Fermentative butanol production: bulk chemical and biofuel. Ann N Y Acad Sci 1125:353-362.

14. Dong H, Tao W, Dai Z, Yang L, Gong F, Zhang Y, Li Y (2011) Biobutanol. Adv Biochem Eng Biotechnol. doi:10.1007/10_2011_128.

15. Werpy T, Petersen B (2004) Top value added chemicals from biomass 1. Available via http://www.eere.energy.gov/biomass/pdfs/pnnl-16983.pdf. Accessed 27 June 2012.

16. Busch R, Hirth T, Liese A, Nordhoff S, Puls J, Pulz O, Sell D, Syldatk C, Ulber R (2006) The utilization of renewable resources in German industrial production. Biotechnol J 1(7-8):770-776.

17. Marner WD, 2nd (2009) Practical application of synthetic biology principles. Biotechnol J 4(10):1406-1419.

18. Tang WL, Zhao H (2009) Industrial biotechnology: tools and applications. Biotechnol J 4(12):1725-1739.

19. Zeng AP, Biebl H (2002) Bulk chemicals from biotechnology: the case of 1,3-propanediol production and the new trends. Adv Biochem Eng Biotechnol 74:239-259.

20. McKinlay JB, Vieille C, Zeikus JG (2007) Prospects for a bio-based succinate industry. Appl Microbiol Biotechnol 76(4):727-740.

21. Anastassiadis S, Morgunov IG (2007) Gluconic acid production. Recent Pat Biotechnol 1(2):167-180.

22. Steudel A, Miethe D, Babel W (1980) Bacterium MB 58, a methylotrophic "acetic acid bacterium". Z Allg Mikrobiol 20(10):663-672.

23. Ramachandran S, Fontanille P, Pandey A, Larroche C (2006) Gluconic acid: a review: properties, applications and microbial production. Food Technol Biotechnol 44(2):185-195.

24. Anastassiadis S, Morgunov IG, Kamzolova SV, Finogenova TV (2008) Citric acid production patent review. Recent Pat Biotechnol 2(2):107-123.

25. Müller RH, Rohwerder T, Harms H (2007) Carbon conversion efficiency and limits of productive bacterial degradation of methyl tert-butyl ether and related compounds. Appl Environ Microbiol 73(6):1783-1791.

26. Bai FW, Anderson WA, Moo-Young M (2008) Ethanol fermentation technologies from sugar and starch feedstocks. Biotechnol Adv 26(1):89-105.

27. Naik SN, Goud W, Rout PK, Dalai AK (2010) Production of first and second generation biofuels: a comprehensive review. Renew Sust Energ Rev 14 (2):578-597.

28. Demain AL (2009) Biosolutions to the energy problem. J Ind Microbiol Biotechnol 36(3):319-332.

29. Kanowski J, Catterall CP (2010) Carbon stocks in above-ground biomass of monoculture plantations, mixed species plantations and environmental restoration plantings in north-east Australia. Ecol Manag Restor 11(2):119-126

30. Lenk F, Broring S, Herzog P, Leker J (2007) On the usage of agricultural raw materials - energy or food? An assessment from an economics perspective. Biotechnol J 2(12):1497-1504

31. Thrän D, Kaltschmitt M (2007) Competition - supporting or preventing an increased use of bioenergy? Biotechnol J 2(12):1514-1524.
32. Carere C, Sparling R, Cicek N, Levin D (2008) Third generation biofuels via direct cellulose fermentation. Int J Mol Sci 9(7):1342-1360.

33. Demirbas FM (2009) Biorefineries for biofuel upgrading: a critical review. Appl Energy 86 Supplement 1(0):S151-S161.

34. Hermann BG, Blok K, Patel MK (2007) Producing bio-based bulk chemicals using industrial biotechnology saves energy and combats climate change. Environ Sci Technol 41(22):7915-7921.

35. Bak T, Nowotny J, Rekas M, Sorrell CC (2002) Photo-electrochemical hydrogen generation from water using solar energy. Materials-related aspects. Int J Hydrogen Energy 27(10):991-1022.

36. Sherif SA, Barbir F, Veziroglu TN (2005) Wind energy and the hydrogen economy - review of the technology. Sol Energy 78(5):647-660.

37. Peters M, Köhler B, Kuckshinrichs W, Leitner W, Markewitz P, Müller TE (2011) Chemical technologies for exploiting and recycling carbon dioxide into the value chain. Chem Sus Chem 4(9):1216-1240.

38. Cokoja M, Bruckmeier C, Rieger B, Herrmann WA, Kühn FE (2011) Transformation of carbon dioxide with homogeneous transition-metal catalysts: a molecular solution to a global challenge? Angew Chem Int Ed Engl 50(37):8510-8537.

39. Pelzer S (2012) Maßgeschneiderte Mikroorganismen. Biol Unserer Zeit 42(2):98-106.

40. Hermann BG, Patel M (2007) Today's and tomorrow's bio-based bulk chemicals from white biotechnology: a techno-economic analysis. Appl Biochem Biotechnol 136(3):361-388.

41. Rohwerder T, Breuer U, Benndorf D, Lechner U, Müller RH (2006) The alkyl tert-butyl ether intermediate 2-hydroxyisobutyrate is degraded via a novel cobalamin-dependent mutase pathway. Appl Environ Microbiol 72(6):4128-4135

42. Rohwerder T, Müller RH (2007) New bacterial cobalamin-dependent CoA-carbonyl mutases involved in degradation pathways. In: Elliot CM (ed) Vitamin B: new research. Nova Science Publishers, New York, pp 81-98.

43. Müller RH, Rohwerder T (2007) Method for the enzymatic production of 2-hydroxy-2-methyl carboxylic acids. http://patentscope.wipo.int/search/en/ WO2007110394. Accessed 27 June 2012.

44. Yaneva N, Schuster J, Schäfer F, Lede V, Przybylski D, Paproth T, Harms H, Müller RH, Rohwerder T (2012) A bacterial acyl-CoA mutase specifically catalyzes coenzyme B12-dependent isomerization of 2-hydroxyisobutyryl-CoA and (S)-3-hydroxybutyryl-CoA. J Biol Chem. doi:10.1074/jbc.M111.314690.

45. Höfel T, Wittmann E, Reinecke L, Weuster-Botz D (2010) Reaction engineering studies for the production of 2-hydroxyisobutyric acid with recombinant Cupriavidus necator $\mathrm{H}$ 16. Appl Microbiol Biotechnol 88(2):477-484.

46. Schlegel HG (1954) The role of molecular hydrogen in the metabolism of microorganisms. Arch Mikrobiol 20(3):293-322

47. Schlegel HG, Lafferty R, Krauss I (1970) The isolation of mutants not accumulating poly-beta-hydroxybutyric acid. Arch Mikrobiol 71(3):283-294.

48. Reinecke L, Schaffer S, Marx A, Pötter M, Haas T (2009) Recombinant cell producing 2-hydroxyisobutyric acid. http://patentscope.wipo.int/search/en/ WO2009156214. Accessed 27 June 2012

49. Kovach ME, Elzer PH, Hill DS, Robertson GT, Farris MA, Roop RM, Peterson KM (1995) Four new derivatives of the broad-host-range cloning vector PBBR1MCS, carrying different antibiotic-resistance cassettes. Gene 166(1):175-176.

50. Schlegel HG, Kaltwasser H, Gottschalk G (1961) Ein Submersverfahren zur Kultur wasserstoffoxydierender Bakterien: Wachstumsphysiologische Untersuchungen. Arch Microbiol 38(3):209-222.

51. van Dijken JP, Harder W (1975) Growth yields of microorganisms on methanol and methane. A theoretical study. Biotechnol Bioeng 17(1):15-30.

52. Babel W, Müller RH (1985) Correlation between cell composition and carbon conversion efficiency in microbial growth: a theoretical study. App Microbiol Biotechnol 22(3):201-207.

53. Stouthamer AH (1973) A theoretical study on the amount of ATP required for synthesis of microbial cell material. A Van Leeuw J Microb 39(3):545-565.

54. Repaske R, Mayer R (1976) Dense autotrophic cultures of Alcaligenes eutrophus. Appl Environ Microbiol 32(4):592-597.

55. Ishizaki A, Tanaka K (1991) Production of poly- $\beta$-hydroxybutyric acid from carbon dioxide by Alcaligenes eutrophus ATCC 17697 T. J Ferment Bioeng 71(4):254-257. 
56. Ishizaki A, Tanaka K (1990) Batch culture of Alcaligenes eutrophus ATCC 17697 T using recycled gas closed circuit culture system. J Ferment Bioeng 69(3):170-174

57. Steinbüchel A, Schlegel HG (1989) Excretion of pyruvate by mutants of Alcaligenes eutrophus, which are impaired in the accumulation of poly( $\beta$-hydroxybutyric acid) (PHB), under conditions permitting synthesis of PHB. Appl Microbiol Biotechnol 31(2):168-175.

58. Lenz O, Schwartz E, Dernedde J, Eitinger M, Friedrich B (1994) The Alcaligenes eutrophus $\mathrm{H} 16$ hoxX gene participates in hydrogenase regulation. J Bacteriol 176(14):4385-4393.

59. Burgdorf $\mathrm{T}$, Lenz $\mathrm{O}$, Buhrke T, van der Linden E, Jones AK, Albracht SP, Friedrich B (2005) [NiFe]-hydrogenases of Ralstonia eutropha H16: modular enzymes for oxygen-tolerant biological hydrogen oxidation. J Mol Microbiol Biotechnol 10(2-4):181-196.

60. Husemann M, Klintworth R, Büttcher V, Salnikow J, Weissenborn C, Bowien B (1988) Chromosomally and plasmid-encoded gene clusters for $\mathrm{CO}_{2}$ fixation (cfx genes) in Alcaligenes eutrophus. Mol Gen Genet MGG 214(1):112-120.

61. Vollbrecht D, Nawawy MA, Schlegel HG (1978) Excretion of metabolites by hydrogen bacteria I. Autotrophic and heterotrophic fermentations. Appl Microbiol Biotechnol 6(2):145-155.

62. Vollbrecht D, Schlegel HG (1978) Excretion of metabolites by hydrogen bacteria II. Influences of aeration, pH, temperature, and age of cells. Appl Microbiol Biotechnol 6(2):157-166.

63. Vollbrecht D, Schlegel HG, Stoschek G, Janczikowski A (1979) Excretion of metabolites by hydrogen bacteria. Appl Microbiol Biotechnol 7(3):267-276.

64. Tanaka K, Ishizaki A, Kanamaru T, Kawano T (1995) Production of poly(D-3-hydroxybutyrate) from $\mathrm{CO}(2), \mathrm{H}(2)$, and $\mathrm{O}(2)$ by high cell density autotrophic cultivation of Alcaligenes eutrophus. Biotechnol Bioeng 45(3):268-275

65. Sonnleitner B, Heinzle E, Braunegg G, Lafferty RM (1979) Formal kinetics of poly- $\beta$-hydroxybutyric acid (PHB) production in Alcaligenes eutrophus H 16 and Mycoplana rubra R 14 with respect to the dissolved oxygen tension in ammonium-limited batch cultures. Appl Microbiol Biotechnol 7(1):1-10.

66. Schubert P, Steinbuchel A, Schlegel HG (1988) Cloning of the Alcaligenes eutrophus genes for synthesis of poly-beta-hydroxybutyric acid (PHB) and synthesis of PHB in Escherichia coli. J Bacteriol 170(12):5837-5847.

67. Müller RH, Babel W (1996) Measurement of growth at very low rates $(\mu \geq 0)$, an approach to study the energy requirement for the survival of Alcaligenes eutrophus JMP 134. Appl Environ Microbiol 62(1):147-151.

68. Lee SE, Li QX, Yu J (2009) Diverse protein regulations on PHA formation in Ralstonia eutropha on short chain organic acids. Int J Biol Sci 5(3):215-225.

69. Russell JB (1992) Another explanation for the toxicity of fermentation acids at low pH: anion accumulation versus uncoupling. J Appl Microbiol 73(5):363-370.

70. Chung YJ, Cha HJ, Yeo JS, Yoo YJ (1997) Production of poly(3-hydroxybutyric-co-3-hydroxyvaleric)acid using propionic acid by pH regulation. J Ferment Bioeng 83(5):492-495.

71. Wang J, Yu J (2000) Kinetic analysis on inhibited growth and poly(3-hydroxybutyrate) formation of Alcaligenes eutrophus on acetate under nutrient-rich conditions. Process Biochem 36(3):201-207.

72. Du G, Si Y, Yu J (2001) Inhibitory effect of medium-chain-length fatty acids on synthesis of polyhydroxyalkanoates from volatile fatty acids by Ralstonia eutropha. Biotechnol Lett 23(19):1613-1617.

73. Yu J, Wang J (2001) Metabolic flux modeling of detoxification of acetic acid by Ralstonia eutropha at slightly alkaline $\mathrm{pH}$ levels. Biotechnol Bioeng 73(6):458-464

74. Greiner CJ, KorpÅs M, Holen AT (2007) A Norwegian case study on the production of hydrogen from wind power. Int J Hydrogen Energy 32(10-11):1500-1507.

75. Phillips J, Clausen E, Gaddy J (1994) Synthesis gas as substrate for the biological production of fuels and chemicals. Appl Biochem Biotechnol 45-46(1):145-157.

76. Digman B, Joo HS, Kim DS (2009) Recent progress in gasification/pyrolysis technologies for biomass conversion to energy. Environ Prog \& Sustainable Energy 28(1):47-51.

\section{Submit your manuscript to a SpringerOpen ${ }^{\circ}$ journal and benefit from:}

- Convenient online submission

- Rigorous peer review

- Immediate publication on acceptance

- Open access: articles freely available online

- High visibility within the field

- Retaining the copyright to your article

Submit your next manuscript at $\gg$ springeropen.com 